\title{
APONTAMENTOS SOBRE O SISTEMA DE CONTROLE DE CONSTITUCIONALIDADE DOS ATOS NORMATIVOS MUNICIPAIS
}

\author{
NOTES ON THE JUDICIAL REVIEW SYSTEM OVER MUNICIPAL ACTS
}

João Pedro Accioly

Graduado em Direito e Mestrando em Direito Público pela Universidade do Estado do Rio de Janeiro - UERJ. Advogado e Consultor Jurídico em Direito Administrativo e

Constitucional. E-mail: jacciolyteixeira@gmail.com

Recebido em: 06/12/2016

Aprovado em: 13/03/2017

Doi: $10.5585 /$ rdb.v17i7.552

RESUMO: O propósito deste trabalho é analisar, descritiva e prescritivamente, o sistema de controle de constitucionalidade dos atos normativos comunais. Além de um breve estudo acerca das premissas teóricas que legitimam e moldam a jurisdição constitucional sobre as normas municipais, examinar-se-á individualizadamente os mecanismos de controle de constitucionalidade à disposição da Câmara de Vereadores, do Prefeito e do Poder Judiciário. Ademais, defender-se-á que a constitucionalidade das normas municipais depende de sua cumulativa compatibilidade com a Constituição Federal, com a Constituição do Estado envolvente e com a Lei Orgânica do Município respectivo - cujo status constitucional será também defendido. Ao fim do artigo, trata-se, com especial profundidade, justamente das ferramentas de tutela da supremacia da Lei Orgânica do Município, tema particularmente negligenciado pela doutrina.

Palavras-chave: Controle de Constitucionalidade Municipal. Autonomia Municipal. Controle Político. Controle Judicial. Lei Orgânica Municipal.

\begin{abstract}
The purpose of this work is to analyze, descriptively and prescriptively, the review of communal normative acts. After a brief study of the theoretical premises that legitimize and shape the constitutional jurisdiction over municipal norms, the control mechanisms available to the City Council, the Mayor and the Judiciary Branch will be individually examined. In addition, it will be defended that the constitutionality of the municipal norms depends on its cumulative compatibility with the Federal Constitution, with the Constitution of the surrounding State and with the Organic Law of the respective Municipality - whose constitutional status will also be defended. Lastly, we will examine the guardianship tools of Municipality Organic Law supremacy, a theme particularly neglected by the doctrine.
\end{abstract}

Key words: Judicial Review. County Acts. Municipal Autonomy. Political Control. Municipal Organic Law. 
SUMÁRIO: 1. Nota Introdutória; 2. Supremacia da Constituição, Controle de Constitucionalidade e Federalismo; 2.1. Autonomia municipal e natureza constitucional da Lei Orgânica do Município; 3. Mecanismos de Controle Político; 3.1. Incumbências da Câmara Municipal: 3.1.1. O papel da CCJ; 3.1.2. Os mecanismos sustatórios; 3.1.3. O controle de constitucionalidade pela via legislativa; 3.2. Incumbências do Prefeito: 3.2.1. Veto por Inconstitucionalidade; 3.2.2. Recusa ao cumprimento de lei reputada inconstitucional; 3.2.3. Poder regulamentar e interpretação conforme a Constituição; 3.2.4. Legitimidade para a propositura de ações impugnativas de leis inconstitucionais; 4. Tríplice Parâmetro no Controle Judicial; 4.1. Constituição Federal; 4.2. Constituição do Estado; 4.3. Lei Orgânica do Município; 4.3.1. Controle Difuso; 4.3.2. O Papel do Mandado de Segurança no Controle de Constitucionalidade no Curso do Processo Legislativo Municipal; 4.3.3. Podem as Constituições Estaduais Criar Mecanismo para o Controle Concentrado das Normas Municipais, pelo Tribunal de Justiça, tendo como Parâmetro a Lei Orgânica?; 5. Proposições conclusivas; Referências bibliográficas.

\section{NOTA INTRODUTÓRIA}

A vasta produção doutrinária acerca dos mecanismos de controle de constitucionalidade não tem abrangido equanimemente os variados âmbitos e formatos em que tal fenômeno se verifica. Nesse contexto, os mecanismos de controle incidentes sobre a produção normativa comunal têm sido, de um modo geral, objeto de especial desinteresse da doutrina ${ }^{1}$ - fato que explica, em parte, o grande número de lacunas e nós que ainda embaraçam esse relevante tema.

Cientes desse panorama, dedicaremos o tópico seguinte a analisar en passant as premissas teóricas sobre as quais se fundamentam o controle de constitucionalidade e a posicionar o Município na heterodoxa lógica tridimensional do Estado Federal brasileiro, analisando especialmente os limites de sua autonomia e a natureza jurídica de sua Lei Orgânica.

Em seguida, estudaremos os mecanismos políticos de controle de constitucionalidade a cargo da Câmara Municipal - sobretudo o papel da CCJ e dos atos sustatórios parlamentares - e do Prefeito, especialmente o poder de veto, a prerrogativa de recusar o cumprimento de lei reputada inconstitucional e a sua legitimidade ativa para impugnação de tais normas.

No quarto tópico, debruçar-nos-emos sobre os sistemas difuso e concentrado de controle judicial da constitucionalidade das normas municipais, defendendo a existência de três parâmetros autônomos de controle: a Constituição Federal, a Constituição do Estado envolvente e a Lei Orgânica do Município.

No que toca ao controle das normas municipais em face da respectiva Lei Orgânica, tema praticamente inexplorado pela doutrina, analisaremos especificamente $i$ ) o seu exercício pela via incidental (controle difuso); ii) o controle judicial, via Mandado de Segurança impetrado por Vereador, de proposição legislativa contrária à Lei Orgânica e iii) a possibilidade de os Estados-membros instituírem representação de inconstitucionalidade, perante o Tribunal de Justiça, que tenha como objeto as normas municipais e parâmetro a Lei Orgânica.

\section{SUPREMACIA DA CONSTITUIÇÃO, CONTROLE DE CONSTITUCIONALIDADE E FEDERALISMO.}

O controle de constitucionalidade é fenômeno diretamente tributário do reconhecimento da eficácia normativa e da supremacia da Constituição. Até o advento da República, a doutrina

\footnotetext{
${ }^{1}$ Merecem registro, desde já, duas célebres, porém insuficientes, exceções a essa tendência: FERRARI, 2003 e ROCHA, 2003.
} 
hegemônica, no Brasil (assim como no mundo ${ }^{2}$ ), entendia as Constituições como proclamações políticas, verdadeiras cartas de intenções, as quais competiam papéis meramente simbólicos. Marquês de São Vicente, na primeira obra latino-americana sobre Direito Público, bem ilustra essa cosmovisão:

Com effeito, a constituição por si só é pouco mais do que um symbolo de esperanças lisongeiras. É o frontispicio grandioso do edificio representativo, que para não ficar só em simples decoração isolada demanda suas columnas de segurança, seus espaços interiores, que resguardem os direitos publicos e individuaes, que sirvão de officinas da prosperidade social. (BUENO, 1857, p. 45).

O movimento de reconhecimento desses valores - força normativa e supremacia constitucional - esteve associado, ao menos de um modo geral, com as experiências totalitárias da primeira metade do século XX. Nesse contexto conturbado, desvelaram-se os riscos que os corpos políticos ordinários, ainda que eleitoralmente legitimados, propiciam. ${ }^{3}$

A supremacia das Constituições passou a ser defendida, sob o prisma material, com base no fato de que elas nascem com o desiderato último de conter o poder estatal, a cargo de maiorias transitórias ${ }^{4}$, tutelando o regime democrático e os direitos básicos de minorias políticas. A supremacia material ostenta, pois, um caráter ontológico, que deriva do conteúdo típico das Constituições: definir a distribuição do poder político (Separação dos Poderes), estabelecer o processo legislativo infraconstitucional (norma normarum, na expressão kelseniana), prever os ritos para o exercício do Poder Constituinte Derivado e consagrar Direitos Fundamentais.

Ademais, argumenta-se que o momento de manifestação do Poder Constituinte Originário é capaz de mobilizar contingentes populacionais expressivos, despertar atenção excepcional da mídia e da sociedade civil e, em face do ânimo de definitividade da Carta a ser promulgada, inspirar nos atores políticos preocupações e motivações menos circunstanciais e

\footnotetext{
${ }^{2}$ A experiência histórica norte-americana é a verdadeira exceção a esta regra. As premissas que viabilizaram o controle de constitucionalidade remontam aos célebres escritos dos Federalistas, especialmente ao artigo $\mathrm{n}^{\mathbf{o}} 78$ de Alexander Hamilton (1788), e ao leading case Marbury vs. Madison (1803). Na Europa, sob os auspícios da obra de Kelsen, duas primeiras experiências de controle de constitucionalidade tiveram lugar durante o interstício entre as Guerras Mundiais. As Constituições da Checoslováquia e da Áustria, ambas promulgadas em 1920, instituíram os primeiros Tribunais Constitucionais Europeus de que se tem notícia. Contudo, como a seguir registrado, somente com o segundo pós-guerra o controle de constitucionalidade espraiou-se mundo afora - conquistando, em variados graus de intensidade e formatos, inclusive países que outrora tão fortemente a ele se opuseram, a exemplo da França (a propósito, v. ACCIOLY, 2016, p. 231-246) e, na concepção de alguns autores, até mesmo da Inglaterra (CYRINIO, 2007, p. 267-288).

${ }^{3} \mathrm{Na}$ concepção de Barroso, o florescimento de robustos sistemas de jurisdição constitucional está intimamente "conectado ao final da Segunda Grande Guerra. A partir daí, o mundo deu-se conta de que a existência de um Poder Judiciário independente e forte é um importante fator de preservação das instituições democráticas e dos direitos fundamentais" (BARROSO, 2015, p. 28).

${ }^{4}$ Não é raro invocar-se, neste ponto, a teoria dos pré-compromissos constitucionais. O tema é bem explicado por Daniel Sarmento nos seguintes termos: "Basta reconhecer que existem certos valores - não importa se históricos ou transcendentais - que são tão importantes que devem se subtraídos da luta política cotidiana. Uma conhecida versão desta justificativa é a teoria do pré-compromisso, bem simbolizada pela história grega de Ulisses e das sereias, contada no Canto XII da Odisseia de Homero. O barco de Ulisses passaria ao largo da ilha das sereias, cujo canto é irresistível, levando sempre os marujos a se descontrolarem e a naufragarem. Sabendo disso, o herói mitológico ordena aos marinheiros que tapem os próprios ouvidos com cera, e que amarrem os braços dele, Ulisses, ao mastro do navio, para impedir que conduzisse o barco em direção à ilha. (...) Ulisses instituiu um pré-compromisso: ciente das suas paixões e fraquezas futuras, dela se protegeu. Na teoria constitucional, traça-se um paralelo entre essa estratégia do herói grego e a decisão do povo de editar uma Constituição, que impõe limitações às suas deliberações futuras. É que o povo, em momentos de maior lucidez, pode também perceber a sua suscetibilidade a cometer erros graves, pondo em risco princípios importantes. Por isso, ele se pré-compromete, por meio de mecanismo que impede que, no futuro, possa sacrificar esses princípios". (SARMENTO; SOUZA NETO, 2013, p. 21).
}

Revista de Direito Brasileira | São Paulo, SP | v. 17 | n. 7 | p. 40 - 62 | Mai./Ago. 2017 
extremadas. Em outros termos, seriam as Constituições imbuídas de especial legitimidade democrática, eis que a sua elaboração congregaria extraordinariamente elementos que não poderiam ser reunidos, ininterruptamente, no processo político ordinário. ${ }^{5}$

Nos países que adotam Constituições rígidas, a supremacia aventada também repousa sobre um argumento formal insuperável, eis que o processo de alteração do texto constitucional é notadamente mais obstaculizado e rigoroso do que o processo legislativo ordinário. Assim, não haveria sentido em prever um adverso procedimento especial de emendamento constitucional e permitir que as disposições da Carta pudessem ser simplesmente derrogadas por leis ordinárias a elas supervenientes. ${ }^{6}$

Aceita a premissa de que as Constituições ocupam o ápice dos sistemas jurídicos, a consagração de mecanismos de verificação da constitucionalidade das demais normas que compõem o ordenamento exsurgiram, progressivamente ao redor do globo, como um corolário lógico. ${ }^{7}$ Não fosse assim, a premissa com a qual se anuíra seria convertida em verdadeiro "sino sem badalo" : os atos normativos violadores da Constituição, a despeito de receberem a pecha de "inconstitucional", permaneceriam produzindo os seus efeitos.

\subsection{Autonomia municipal e natureza constitucional da Lei Orgânica do Município.}

Feitos esses registros preliminares a respeito da jurisdição constitucional, são cabíveis alguns breves comentários acerca da forma federativa do Estado brasileiro e, especialmente, sobre a posição dos entes municipais no interior dessa estrutura.

Enquanto o Princípio da Separação dos Poderes distribuí o poder político de forma horizontal - entre braços independentes de um mesmo ente (tradicionalmente, os Poderes Executivo, Legislativo e Judiciário) -, o federalismo promove uma significativa distribuição vertical da potestade estatal - em unidades federativas reciprocamente autônomas e harmoniosamente coordenadas nos termos da Constituição Federal.

O processo histórico de formação do Estado brasileiro, contudo, não propiciou o pleno desenvolvimento da lógica federalista. Ao contrário de países como os Estados Unidos, resultantes de um movimento centrípeto, em que antigos Estados Unitários agregaram-se num só

\footnotetext{
${ }^{5}$ Naturalmente, essa linha argumentativa só é aplicável às constituições promulgadas por órgãos democraticamente erigidos. Não é possível cogitá-la no caso das Constituições Outorgadas, que são unilateralmente impostas, nem mesmo no caso das Constituições Cesaristas, em que a população é convocada somente para referendar um documento também unilateralmente formulado. Sobre a classificação das Constituições quanto à sua origem, $c f$. NOVELINO, 2009, p. 105-110.

${ }^{6}$ Embora mecanismos de controle de constitucionalidade constem das Constituições brasileiras desde o advento da República, a efetividade das normas constitucionais é fenômeno muito mais recente - que só teve lugar após a promulgação da Constituição de 1988. BARROSO, 2015, p. 27: "Com a promulgação da Constituição de 1988, teve início a luta teórica e judicial pela conquista de efetividade pelas normas constitucionais. Os primeiros anos de vigência da Constituição de 1988 envolveram o esforço da teoria constitucional para que o Judiciário assumisse o seu papel e desse concretização efetiva aos princípios, regras e direitos inscritos na Constituição. Pode parecer óbvio hoje, mas o Judiciário, mesmo o Supremo Tribunal Federal, relutava em aceitar esse papel. No início dos anos 2000, essa disfunção foi sendo progressivamente superada e o STF foi se tornando, verdadeiramente, um intérprete da Constituição".

${ }^{7}$ Em trabalho anterior, dedicado à análise do modelo contemporâneo de jurisdição constitucional da França, comentamos a relação entre supremacia da Constituição e o desenvolvimento das ferramentas de controle de constitucionalidade: "a trajetória francesa evidencia a intrínseca relação existente entre a noção de supremacia da Constituição e os mecanismos de controle de constitucionalidade. O movimento de reconhecimento da força normativa da Constituição e de sua posição de cúspide do sistema jurídico francês impôs a progressiva instituição de mecanismos de aferição da compatibilidade das leis em relação à Constituição" (ACCIOLY, 2016, p. 244).

${ }^{8}$ A expressão foi consagrada por José Carlos Barbosa Moreira, em célebre artigo intitulado "SOS para o Mandado de Injunção", que foi publicado no Jornal do Brasil, no dia 11.09.1990.
} 
Estado Soberano, a Federação brasileira tem origem da desagregação do Estado Monárquico (uno por excelência), que fora suplantado em 1889.

Por força dessa discrepância, enquanto as unidades federativas norte-americanas receberam amplas competências legislativas, administrativas e tributárias, às brasileiras delegouse ínfima fração do poderio Estatal. Como se não bastasse, as competências outorgadas aos entes regionais e locais não raro foram ainda mais constritas por obra de uma cultura jurídica centralizadora, em grande medida sem respaldo da Constituição de $1988 .^{9}$

Parece possível constatar que, de um modo geral, a ordem constitucional brasileira não promove intensamente a lógica federalista. Essa característica do sistema foi, contudo, levada por parte da doutrina a um ponto culminante jamais imaginado nem, muito menos, pretendido pelo Constituinte. Daí, por exemplo, diversos autores negarem, contra a letra expressa da Lei Maior ${ }^{10}$, que os Municípios constituam entidades federativas. ${ }^{11}$ Trata-se de uma tentativa de superar uma legítima $^{12}$ e cristalina escolha do Constituinte e impor uma concepção idealizada de Federação, forjada essencialmente com base na particular experiência história estadunidense.

$\mathrm{Na}$ mesma esteira, muitos autores negam o caráter constitucional das Leis Orgânicas Municipais, classificando-as como produtos da "mera elaboração legislativa da Câmara de Vereadores" (ARAUJO; NUNES JUNIOR, 2006, p. 299). Aceita essa premissa, inexistiriam quaisquer meios de controle da juridicidade dos atos normativos municipais expedidos em desconformidade com as disposições da respectiva Lei Orgânica: prevaleceria o diploma mais recente. $^{13}$

Essa conclusão, com a devida vênia, parece-nos ilógica. Em primeiro lugar, as Leis Orgânicas constituem o produto máximo da autonomia política e organizativa dos entes comunais: nela estão inscritas normas materialmente constitucionais indispensáveis à básica estruturação e ao adequado funcionamento do Município. Em segundo lugar, mas talvez mais importante, não se pode olvidar que o caput do art. 29, da Constituição de 1988, prevê que a Lei Orgânica Municipal deve ser "votada em dois turnos, com o interstício mínimo de dez dias, e aprovada por dois terços dos membros da Câmara Municipal".

Assim, além do seu conteúdo normativo ser materialmente constitucional, as Leis Orgânicas Municipais constituem, do ponto de vista formal, diploma de insuspeita rigidez. ${ }^{14}$

\footnotetext{
${ }^{9}$ Não são poucas nem desarrazoadas as críticas dirigidas ao emprego exacerbado do princípio da simetria para limitar a autonomia dos entes federados. Destacados autores sugerem, a nosso ver acertadamente, que a própria existência do referido princípio não possuí amparo na ordem constitucional vigente. Nesse sentido, v. SARMENTO; SOUZA NETO, 2013, p. 333-335.

${ }^{10}$ Dentre outros dispositivos constitucionais que explicitam o ponto, podemos mencionar o caput do art. $1^{\circ}$ - "A República Federativa do Brasil, formada pela união indissolúvel dos Estados e Municípios e do Distrito Federal, constitui-se em Estado Democrático de Direito" - e o caput do art. 18: "A organização político-administrativa da República Federativa do Brasil compreende a União, os Estados, o Distrito Federal e os Municípios, todos autônomos, nos termos desta Constituição".

11 José Afonso da Silva (2011, p. 101), por exemplo, defende que: "Foi equívoco do constituinte incluir os Municípios como componentes da federação. Município é divisão política do Estado-membro". No mesmo sentido, v. CASTRO, 2010, p. 27 e HORTA, 1995, p. 622.

${ }^{12}$ ZIMMERMANN, 2005, 47-48: "afrontando a dualidade federativa mais clássica, acrescentou o federalismo pátrio esta esfera autonomista municipal, mas que é absolutamente salutar, tendo-se por vista a grandeza do nosso território nacional e, ademais, de boa parte dos Estados-membros componentes desta Federação". TOCQUEVILLE, 1973, p. 202: "É na comuna que reside a força dos povos livres. As instituições municipais estão para a liberdade como as escolas primárias estão para a ciências: põem-na ao alcance do povo. Sem instituições comunais, uma nação pode dar-se um governo livre, mas não tem o espírito de liberdade".

${ }^{13}$ Outra parcela da doutrina, embora negue o caráter constitucional da Lei Orgânica, admite a sua superioridade formal em relação às demais normas municipais, entendendo que estas podem ser objeto de mero controle de legalidade.

${ }^{14}$ Dúvida doutrinária há sobre qual seria o quórum exigido para a aprovação de emendas às Leis Orgânicas Municipais. Regina Maria Macedo Nery Ferrari defende, na linha do que dispõe o art. 29 da CRFB/88, que tais Revista de Direito Brasileira | São Paulo, SP | v. 17 | n. 7 | p. 40 - 62 | Mai./Ago. 2017
} 
Parece fora de dúvida, pois, que as Leis Orgânicas são produtos do exercício do Poder Constituinte Decorrente, ainda que em modalidade mais limitada em relação àquela verificada no plano estadual. Aceita essa tese, forçoso será reconhecer - como meio assecuratório da supremacia da lei orgânica - a possibilidade de se controlar, tendo ela como parâmetro, a constitucionalidade dos demais atos normativos do respectivo município.

Para encerrar o tópico, é relevante pontuar ainda que não existe uma relação de plena subalternidade entre a Lei Orgânica do Município e a Constituição do Estado que o abrange territorialmente. Embora a Constituição Federal preveja que as Leis Orgânicas Municipais devam observar os princípios estabelecidos "na Constituição do respectivo Estado", o Supremo Tribunal Federal, acertadamente, tem extirpado do ordenamento normas estaduais, ainda que inscritas nas respectivas Constituições, que atentem contra a autonomia dos municípios. ${ }^{15}$ Nesse sentido, revela-se oportuno transcrever trecho de lapidar decisão do Ministro Sepúlveda Pertence:

Dar alcance irrestrito à alusão, no art. 29, caput, CF, à observância devida pelas leis orgânicas municipais aos princípios estabelecidos na Constituição do Estado, traduz condenável misoneísmo constitucional, que faz abstração de dois dados novos e incontornáveis do trato do Município da Lei fundamental de 1988: explicitar o seu caráter de "entidade infraestatal rígida" e, em consequência, outorgar-lhe o poder de auto-organização, substantivado, no art. 29, pelo de votar a própria lei orgânica. É mais que bastante ao juízo liminar sobre o pedido cautelar a aparente evidência de que em tudo quanto, nos diversos incisos do art. 29, a Constituição da República fixou ela mesma os parâmetros limitadores do poder de auto-organização dos Municípios e excetuados apenas aqueles que contém remissão expressa ao direito estadual (art. 29, VI, IX e X) - a Constituição do Estado não os poderá abrandar nem agravar. (STF, Tribunal Pleno, ADI 2.112 MC, Rel. Min. Sepúlveda Pertence, DJ de 18.05.2001).

Em outros termos, o Município só estará sujeito à disciplina jurídica que lhes queira dar o Estado envolvente nas hipóteses previstas pela Constituição Federal. Nada obstante, mesmo nesses casos, as normas estaduais jamais podem ferir de morte a autonomia municipal especialmente as prerrogativas e as competências asseguradas pela CRFB/88 aos entes locais, sob pena de sua inconstitucionalidade.

emendas só podem ser consideradas como aprovadas se contarem com o voto de dois terços dos vereadores que componham a Câmara (2005, p. 109/110). Daniel Sarmento e Cláudio Pereira de Souza Neto assinalam que concordam "com a existência de rigidez, mas não com a necessidade de reforma da lei orgânica pelo quórum de $2 / 3$ dos vereadores. As Constituições Estaduais, por exemplo, foram aprovadas por maioria absoluta e não são reformadas pela mesma votação - o STF, como visto acima, entende que só podem ser modificadas pelo quórum de 3/5" (2013, p. 337, nota de rodapé $\left.n^{\circ} 175\right)$. De minha parte, tendo a concordar com a primeira posição. Isso porque, ao contrário do que ocorre com os Estados, há norma constitucional expressa e específica disciplinam o quórum para o exercício do Poder Constituinte Decorrente pelos entes comunais - sendo este ainda mais elevado do que o exigido para a reforma da Constituições Federal e, pela via da simetria, também das Constituições estaduais. Felizmente, a controvérsia suscitada tem se revelado mais teórica do que prática, eis que os Municípios em geral estabeleceram, nas suas respectivas Leis Orgânicas, que estas só podem ser emendadas por proposições que obtenham o voto de dois terços dos Vereadores. Este é o caso, por exemplo, dos Munícipios de São Paulo, do Rio de Janeiro e de Belo Horizonte.

${ }^{15}$ Ilustrativa dessa tendência jurisprudencial do STF é a ADI 144, relatada pelo Min. Gilmar Mendes, publicada em 03.04.2014. Nessa oportunidade, o Tribunal entendeu que norma da Constituição do Rio Grande do Norte que fixava data-limite para o pagamento de servidores públicos municipais consistia, nos termos do voto do Ministro Relator, "disposição de flagrante violação à autonomia administrativa e financeira municipal, disposta nos arts. 29; 30, I; e 34, VII, c, da Constituição Federal”. No mesmo sentido, cite-se ainda os seguintes julgados: ADI 3.548, Rel. Min. Cármen Lúcia, DJe 31.10.2007 e ADI 845, Rel. Min. Eros Grau, DJe 07.03.2008. 
Feitas essas considerações propedêuticas, passa-se a analisar individualizadamente, nos tópicos e subtópicos seguintes, os diversos mecanismos de controle de constitucionalidade da produção normativa municipal existentes no Direito brasileiro.

\section{MECANISMOS DE CONTROLE POLÍTICO}

Quando se fala em controle de constitucionalidade, logo se pensa nos mecanismos judiciais - incidentais e abstratos - de verificação da compatibilidade dos atos normativos com a Constituição. Contudo, o controle de constitucionalidade não é uma atribuição privativa de autoridades do Poder Judiciário. Os demais Poderes, que no âmbito municipal são exercidos pela Câmara de Vereadores e pelo Prefeito, também possuem instrumentos para o desempenho de tal mister.

Em geral, os mecanismos de controle político são manejados de modo preventivo, ainda no curso do processo legislativo. Todavia, também existem ferramentas de controle político repressivas, isto é, aptas a expurgar da ordem jurídica atos normativos que já tenham entrado em vigor. É o caso, dentre outros, dos atos de sustação parlamentar de normas inconstitucionais.

Outra característica do sistema político de controle de constitucionalidade é a prospectividade dos seus efeitos. Diversamente do controle judicial, que em regra possuí efeitos retroativos, os mecanismos políticos possuem eficácia ex nunc - interrompendo o processo de produção da norma inquinada, paralisando a sua eficácia, negando a sua aplicabilidade ou a revogando do ordenamento. Estudaremos em seguida cada um deles.

\subsection{Incumbências da Câmara Municipal:}

\subsubsection{O papel da CCJ}

Assim como nas demais Casas Legislativas, há nas Câmaras Municipais uma Comissão Permanente responsável por, dentre outras atribuições, apreciar a constitucionalidade de todas as proposições legislativas apresentadas.

A disciplina e os efeitos jurídicos dos pareceres exarados por tais órgãos, correntemente designados de Comissão de Constituição e Justiça - CCJ, são geralmente regulados em sede regimental. No mais das vezes, os pareceres das Comissões de Constituição e Justiça são meramente opinativos. De todo modo, ante a jurisprudência do STF a respeito do enforceability das normas interna corporis, ${ }^{16}$ ainda que o regimento parlamentar preveja a sua vinculatividade,

\footnotetext{
${ }^{16}$ STF, MS 33705 AgR, Rel. Min. Celso de Mello, Tribunal Pleno, DJe 29.03.2016: "IMPETRAÇÃO CONTRA ATO DA MESA DO CONGRESSO NACIONAL QUE APROVOU A NOMEAÇÃO DOS INTEGRANTES DO CONSELHO DE COMUNICAÇÃO SOCIAL - ALEGADA INOBSERVÂNCIA DO RITO PROCEDIMENTAL EM SUA COMPOSIÇÃO - PRETENSÃO DOS IMPETRANTES, ENTRE OS QUAIS DIVERSAS ENTIDADES DE DIREITO PRIVADO, AO CONTROLE JURISDICIONAL DO "ITER" FORMATIVO CONCERNENTE A REFERIDO ÓRGÃO COLEGIADO - LEGITIMIDADE ATIVA, PARA ESSE EFEITO, APENAS DOS CONGRESSISTAS - DELIBERAÇÃO DE NATUREZA "INTERNA CORPORIS" - NÃO CONFIGURAÇÃO, EM REFERIDO CONTEXTO, DA COMPETÊNCIA DO PODER JUDICIÁRIO - HIPÓTESE DE INCOGNOSCIBILIDADE DA AÇÃO DE MANDADO DE SEGURANÇA - PRECEDENTES DO SUPREMO TRIBUNAL FEDERAL - RECURSO DE AGRAVO IMPROVIDO. - Não se revela admissível mandado de segurança, sob pena de ofensa ao postulado nuclear da separação de poderes $\left(\mathrm{CF}\right.$, art. $2^{\circ}$ ), quando impetrado com o objetivo de questionar divergências "interna corporis" e de suscitar discussões de natureza regimental: apreciação vedada ao Poder Judiciário, por tratar-se de temas que devem ser resolvidos na esfera de atuação do próprio Congresso Nacional (ou das Casas que o integram). - A submissão das questões de índole regimental ao poder de supervisão jurisdicional dos Tribunais implicaria, em última análise, caso admitida, a inaceitável nulificação do próprio Poder Legislativo, especialmente em matérias em que não se verifica evidência de que o comportamento impugnado tenha efetivamente vulnerado o texto da Constituição da República. Precedentes". No mesmo sentido,
}

Revista de Direito Brasileira | São Paulo, SP | v. 17 | n. 7 | p. 40 - 62 | Mai./Ago. 2017 
é difícil vislumbrar a invalidação judicial de lei que, embora reputada inconstitucional pela CCJ, tenha sido aprovada pela maioria dos vereadores em plenário. A solução apresentada só seria diferente, a nosso ver, se a própria Lei Orgânica Municipal previsse, como requisito do processo legislativo ordinário, a necessidade de parecer favorável da CCJ. ${ }^{17}$

\subsubsection{Os mecanismos sustatórios}

Há dois relevantes e bem diferenciados mecanismos sustatórios de normas antijurídicas a cargo do Poder Legislativo. No plano federal, cabe ao Congresso Nacional sustar os atos normativos expedidos pelo Executivo que exorbitem os limites do poder regulamentar ou da delegação (CF/88, art. 49, V) e ao Senado Federal suspender, no todo ou em parte, lei que tenha sido declarada incidentalmente inconstitucional pelo Supremo Tribunal (CF/88, art. 52, X).

No plano estadual e municipal, em que os Poderes Legislativos são unicamerais, as Assembleias Legislativas e as Câmaras dos Vereadores reúnem ambas as atribuições. Quanto ao mecanismo sustatório dos atos normativos exarados pela Administração Pública, não há grandes particularidades quando do seu exercício no âmbito municipal. ${ }^{18}$ Todavia, enquanto a possibilidade de suspensão de leis municipais declaradas inconstitucionais pelo Judiciário tem se mostrado providência anacrônica à nível federal, ${ }^{19}$ a medida pode ser de grande valia na seara comunal - em que a via do controle de constitucionalidade concentrado, sobretudo perante o Supremo, é estreita ${ }^{20}$ e demorada. ${ }^{21} \mathrm{O}$ mecanismo de suspensão é ainda mais relevante em face de violações à Lei Orgânica do Município - eis que, em regra, não existem expedientes de controle abstrato tendo tal Diploma como parâmetro.

Assim, vereadores vigilantes podem abstratizar algumas declarações de inconstitucionalidade que só podem ser emitidas incidenter tantum e, por isso, também só

MS 34063 AgR/DF, Min. Rel. Luiz Edson Fachin; MS 25588 AgR/DF, Rel. Min. Menezes Direito; MS 20.471/DF, Rel. Min. Francsico Rezek e MS 21.374/DF, Rel. Min. Moreira Alves.

${ }^{17}$ Por ser inovação frente às normas de processo legislativo inscritas na Constituição Federal, provavelmente a constitucionalidade dessa solução seria questionada, por parte da doutrina mais tradicional, com base no princípio da simetria.

${ }^{18}$ Para não adentrarmos nesse tema específico e fugirmos ao objeto do presente estudo, remetemos o leitor ao que a doutrina nacional escreveu sobre a matéria, especialmente: FERRAZ, 1994.

${ }^{19}$ O mecanismo em tela foi introduzido no Direito Constitucional brasileiro com a Carta de 1934, na forma do art. 91, IV, como tentativa de corrigir as incongruências entre a adoção do modelo norte-americano de jurisdição constitucional, difuso por excelência, sem a incorporação do modelo de jurisdição que the é correspondente: o stare decisis. Nas últimas décadas, com o advento de diversas ações diretas (dotadas de efeitos vinculantes e eficácia erga omnes) e o robustecimento institucional do STF, a ferramenta de suspensão caiu em desuso e não mais tem lugar na atual dinâmica entre os Poderes. Nesse particular, Gilmar Mendes defende a conhecida e controversa tese de que o art. 52, X, da CRFB/88, teria sofrido uma mutação constitucional e atuação do Senado Federal serviria apenas para conferir maior publicidade as decisões da Suprema Corte - que, ainda que prolatadas incidentalmente, deveriam desde já alcançar e obrigar a todos. Embora discorde da tese proposta, por achar que a mutação constitucional encontra intransponível barreira nos limites semânticos do texto constitucional, concordo com a sua premissa: o anacronismo da sistemática em apreço, ao menos no plano federal. Sobre o ponto, v. MENDES; BRANCO, 2013, p. 1.093-1.101 e BARROSO, 2012, p. 154-158.

${ }^{20}$ A única ação direta que permite a impugnação de norma municipal perante o STF é a Arguição de Descumprimento de Preceito Fundamental. Como se sabe, contudo, somente as normas alegadamente violadoras de preceitos fundamentais inscritos na Constituição Federal podem ser objeto de tal ação, excluindo-se do seu alcance quaisquer outras modalidades de inconstitucionalidade.

${ }^{21}$ Em segundo lugar, há de se ter em mente que, além do Supremo ser um tribunal excessivamente atarefado, as ações diretas de sua competência acabam sendo julgadas não por ordem cronológica, mas por critérios de relevância social, econômica e política. Nessa esteira, acabam sendo privilegiados os julgamentos de ações que impactem à vida nacional, enquanto se negligencia questões de interesse meramente local.

Revista de Direito Brasileira | São Paulo, SP | v. 17 | n. 7 | p. 40 - 62 | Mai./Ago. 2017 
produzem efeitos inter partes. Essa possibilidade foi expressamente prevista, dentre outras, pela Lei Orgânica do Município de Belo Horizonte:

Art. 84 - Compete privativamente à Câmara Municipal: (...) XIX - suspender, no todo ou em parte, a execução de ato normativo municipal declarado, incidentalmente: a) inconstitucional, por decisão definitiva do Tribunal de Justiça do Estado, quando a decisão de inconstitucionalidade for limitada ao texto da Constituição do Estado; b) infringente desta Lei Orgânica, por decisão definitiva do órgão competente do Poder Judiciário.

\subsubsection{O controle de constitucionalidade pela via legislativa}

A atividade legiferante também pode ser instrumentalizada para fins de controle de constitucionalidade. Há pelo menos três hipóteses em que isso ocorre. Em primeiro lugar, pode a Câmara de Vereadores aprovar emenda à Lei Orgânica com o fito de superar a jurisprudência sobre determinada norma naquela inscrita. ${ }^{22}$ Evidentemente, o poder de alteração da Lei Orgânica está sujeito a diversos limites formais, circunstanciais e, sobretudo, materiais. ${ }^{23}$ Nesses casos, não será dado ao parlamento comunal modificar a Constituição do Município.

Em segundo lugar, podem os Vereadores aprovar Lei, ou mesmo emenda à Lei Orgânica, para fixar uma forma de interpretação, constitucionalmente viável, acerca de dispositivo dúbio, que poderia ser reputado inconstitucional por outros Poderes. Nessa hipótese, o parlamento valer-se-ia, em essência, da técnica da interpretação conforme a Constituição, hoje largamente empregada pelo Supremo Tribunal Federal. ${ }^{24}$

Por derradeiro, embora a Câmara Municipal não possa, pela via legislativa, declarar a inconstitucionalidade de diploma que tenha anteriormente aprovado, compete a ela revogar quaisquer leis municipais em vigor. Naturalmente, ainda que a justificativa da lei revogatória seja a inconstitucionalidade da norma revoganda, aquela não produzirá efeitos retroativos, não tendo o condão de desconstituir as situações jurídicas consolidadas sob a égide lei primitiva.

\subsection{Incumbências do Prefeito:}

\subsubsection{Veto por Inconstitucionalidade}

Os Chefes de Governo, nos três níveis da Federação brasileira, participam intensamente da atividade legiferante. Além de serem dotados da capacidade - privativa, em algumas matérias - de deflagrar o processo legislativo, tais autoridades podem também editar Medidas Provisórias

\footnotetext{
${ }^{22}$ Sobre a utilização desse expediente no Brasil, v. o acurado panorama traçado por BRANDÃO, 2012, p. 289-300.

${ }^{23}$ Além de observar os requisitos formais e circunstanciais que condicionam o seu exercício, tais como o quórum de aprovação e a votação em dois turnos, a reforma da Lei Orgânica encontrará limites não só nas cláusulas pétreas como ocorre com a Constituição Federal -, como também nas normas da Constituição da República que forem consideradas de reprodução obrigatória.

${ }^{24}$ Dentre outros precedentes, v. RE 641320, Rel. Min. Gilmar Mendes, DJe 01.08.2016; ADPF 378 MC, Rel. para o Acórdão Min. Luís Roberto Barroso, DJe 08.03.2016; ADI 4815, Rel. Min. Cármen Lúcia, DJe 01.02.2016 e ADI 524, Rel. para o Acórdão Min. Ricardo Lewandowski, DJe 03.08.2015. Sobre o ponto, $c f$. STRECK, Lenio Luiz. 2002, p. 448-453.
} 
e Leis Delegadas, ${ }^{25}$ convocar urgência constitucional na apreciação de determinada proposição e, por fim, sancionar ou vetar a grande maioria das espécies legislativas. ${ }^{26}$

O direito brasileiro conhece duas espécies de veto: o oposto por inconstitucionalidade e aquele que se funda em motivos de conveniência e oportunidade. Na concepção de MENDES (1997, p. 11-39) e BINENBOJM (2010, p. 259-266), o veto por inconstitucionalidade seria suscetível de apreciação judicial, mediante provocação, pela via mandamental, da maioria parlamentar que aprovara o projeto.

Como se sabe, caso a proposição legislativa aprovada não seja expressa ou tacitamente sancionada, o veto será submetido à apreciação do parlamento, que pode rejeitá-lo mediante o voto da maioria absoluta dos seus membros. Embora não a tenhamos mencionado no tópico próprio, essa se trata, caso o veto derrubado tenha sido oposto por alegado vício de inconstitucionalidade, de outra possibilidade de atuação da Câmara de Vereadores no controle de constitucionalidade.

\subsubsection{Recusa ao cumprimento de lei reputada inconstitucional}

Todos os Poderes interpretam a Constituição. Aliás, como acertadamente destaca a doutrina contemporânea (GOMES, 2016), a construção do sentido das normas constitucionais é tarefa contínua e dialógica, compartilhada até mesmo com atores extrainstitucionais, como os cidadãos e os movimentos sociais.

Não sendo a interpretação constitucional um monopólio do Poder Judiciário, qual seria a conduta aconselhável ao Poder Executivo diante da ocorrência da hipótese de incidência de lei que este repute inconstitucional? Deveria a Administração aplicá-la acriticamente ou negar-lhe aplicação, em reverência à supremacia da Constituição ${ }^{27}$

Antes da promulgação da Carta de 1988, a doutrina e a jurisprudência brasileiras haviam consolidado entendimento pela legitimidade de o Chefe do Poder Executivo deixar de aplicar lei que considerasse incompatível com a Constituição, bem como expedir determinação aos seus subordinados hierárquicos para que do mesmo modo procedessem (BARROSO, 1990, p. 387397).

Com o advento da Constituição vigente, alguns setores da doutrina passaram a defender entendimento diverso, apontando como argumento central para tanto a ampliação dos mecanismos e, especialmente, da legitimidade ativa para deflagrar o exame abstrato da constitucionalidade das leis (SOARES, 1997, p. 519/551 e VELOSO, 2000, p. 317-328). Todavia, mesmo entre os adeptos dessa corrente (MENDES, 2004, p. 312), ressalvou-se a possibilidade de os Prefeitos negarem cumprimento a leis que considerem inconstitucionais - eis que a estes não é garantido acesso à jurisdição constitucional concentrada. ${ }^{28}$

Registra-se, contudo, que a concepção hegemônica anteriormente à Constituição de 1988, no sentido de que os Chefes do Executivo nos três níveis de governo gozam dessa

\footnotetext{
${ }^{25}$ Havia grande controvérsia doutrinária a respeito da existência dessas figuras no âmbito dos Estados e Municípios. O Supremo Tribunal, contudo, decidiu que elas podem ser manejadas, nas unidades federativas regionais e locais, desde que haja expressa previsão na Constituição do Estado ou na Lei Orgânica do Município respectivo. Nesse sentido, v. ADI 2391, Rel. Min. Ellen Gracie, DJ 16.03.2007 e ADI 425, Rel. Min. Maurício Corrêa, DJ 19.12.2003.

${ }^{26}$ Como se sabe, as Emendas Constitucionais e os atos privativos do Congresso (Decretos Legislativos, Resoluções etc.) não se submetem à sanção presidencial.

${ }^{27}$ Cabe registrar que, diante da presunção de constitucionalidade de que gozam as leis da República, não pode o Executivo ser sancionado por cumprir legislação que não tenha sido previamente declarada inconstitucional pelo Poder Judiciário.

${ }^{28}$ Embora essa garantia não tenha sido prevista pela Constituição Federal, veremos no tópico 3.2 .4 que todos os Estados-membros, com exceção do Tocantins, concederam aos Prefeitos e às Câmaras Municipais legitimidade para propor a representação de inconstitucionalidade estadual.
} 
prerrogativa, ainda parece majoritária (BINENBOJM, 2014, p. 270-280 e BARROSO, 2012, p. 92-94).

Assinala-se ainda que a possibilidade de descumprir Lei considerada inconstitucional é privativa dos Chefes de Governo, não sendo facultado a seus auxiliares nem, muito menos, a servidores subalternos fazê-lo. ${ }^{29}$ Por derradeiro, é relevante consignar que essa hipótese deve ser tratada de forma absolutamente excepcional, pois compromete os cânones do Estado de Direito e enseja riscos institucionais severos $^{30}$, caso a Lei seja declarada válida pelo Judiciário posteriormente.

\subsubsection{Poder regulamentar e interpretação conforme a Constituição}

Similar à faculdade legislativa de que tratamos no tópico 3.1.3, menciona-se aqui, ainda que brevemente, a possibilidade de o Poder Executivo expedir regulamentos, com lastro no art. 84, IV, da CRFB/88, em prol de fixar um modo constitucionalmente viável de interpretar dispositivo legal semanticamente dúbio. ${ }^{31}$

\subsubsection{Legitimidade para a propositura de ações impugnativas de leis inconstitucionais ${ }^{32}$}

O extenso elenco de autoridades legitimadas a propor ações direta ao Supremo Tribunal Federal não abrange os Prefeitos nem as Câmaras Municipais. ${ }^{33}$ Ao prever a representação de inconstitucionalidade estadual, a Constituição Federal também não garantiu legitimidade ativa a

\footnotetext{
${ }^{29}$ Imagine-se, nesse sentido, o quadro de insegurança jurídica e desigualdade que se criaria se fosse dado a cada auditor e funcionário da Receita Federal afastar a aplicabilidade das leis que eles considerassem incompatíveis com a Constituição.

${ }^{30} \mathrm{O}$ deliberado descumprimento de Lei constituí crime de responsabilidade (CRFB/88, art. 85, VII) e autoriza a intervenção federal nos Estados (CRFB/88, art. 35, IV), bem como a intervenção estadual nos municípios (CRFB/88, art. 34, VI).

${ }^{31}$ A latere, registra-se que, conforme aliás reconheceu recente decisão do Supremo, a interpretação conforme a Constituição consubstancia inequívoco expediente de controle de constitucionalidade, atraindo inclusive, quando manejado por autoridade judicial, a cláusula da reserva de plenário (CRFB/88, art. 97). Nesse sentido, v. STF, Segunda Turma, Rcl 14872, Rel. Min. Gilmar Mendes, DJe 29.06.2016: “6. Órgão fracionário afastou a aplicação do dispositivo legal sem observância do art. 97 da CF (reserva de plenário). Interpretação conforme a Constituição configura claro juízo de controle de constitucionalidade. Violação à Súmula Vinculante n. 10. 7. É vedado ao Poder Judiciário conceder reajuste com base no princípio da isonomia. Ofensa à Súmula Vinculante 37. 8. Reclamação julgada procedente".

${ }^{32} \mathrm{O}$ sistema de controle de constitucionalidade concentrado brasileiro não admite a legitimação ativa universal. $\mathrm{O}$ dispositivo da Lei da ADPF que pretendia conferir capacidade postulatória a qualquer cidadão (a exemplo do recurso de amparo espanhol, do recurso constitucional alemão e da questão prioritária de constitucionalidade francesa) foi objeto de veto presidencial. O rol de órgãos e autoridades legitimadas a deflagrar a jurisdição constitucional abstrata é, portanto, essencialmente político, como políticas igualmente são as finalidades almejadas por elas ao ajuizarem ações diretas. Essa é uma característica do sistema pátrio de controle concentrado: o imbricamento institucional entre o político e o jurídico. Embora os Tribunais Constitucionais operem (ao menos no plano do dever-ser) sob a lógica jurídica, os seus membros são indicados politicamente e, diante do princípio da inércia judicial e das restrições à capacidade postulatória perante tais Cortes, elas apenas julgam as ações intentadas por autoridades e órgãos também políticos, ainda que não exclusivamente partidários.

${ }^{33}$ A atuação de autoridades comunais no STF foi admitida apenas para propor a edição, revisão ou cancelamento de Súmulas Vinculantes. Nos termos do art. $3^{\circ}, \S 1^{\circ}$, da Lei 11.417/2006, o "Município poderá propor, incidentalmente ao curso de processo em que seja parte, a edição, a revisão ou o cancelamento de enunciado de súmula vinculante, o que não autoriza a suspensão do processo".
}

Revista de Direito Brasileira | São Paulo, SP | v. 17 | n. 7 | p. 40 - 62 | Mai./Ago. 2017 
tais atores institucionais, vedando apenas que a legitimidade ativa para a ação aludida fosse atribuída a um único órgão. ${ }^{34}$

No entanto, todas as Constituições Estaduais, com exceção da Carta do Tocantins, ${ }^{35}$ conferem, aos Prefeitos e às Câmaras Municipais, legitimidade para ajuizar a representação de inconstitucionalidade perante o Tribunal de Justiça. Parte delas, no entanto, limita tal capacidade postulatória às leis e aos atos normativos do Munícipio respectivo, ${ }^{36}$ enquanto outras não fazem qualquer restrição a ela. ${ }^{37}$

No cotidiano forense das ações diretas de inconstitucionalidade estaduais, aliás, os Prefeitos ocupam posição de intenso protagonismo. Segundo TOMIO et al. (2015, p. 106), em denso estudo publicado nesta Revista, o "principal demandante de ADIs estaduais é o Prefeito Municipal (cerca de $60 \%$ das ADIs com cerca de $72 \%$ de taxa de sucesso), que o faz quase que integralmente contra norma municipal $(98,9 \%)$ e em cerca de $60 \%$ dos casos invocando vício de iniciativa".

No geral, como se viu, o Constituinte Decorrente seguiu, neste particular, o espírito do Constituinte Originário - consagrando extensos elencos de autoridades legitimadas a propor a representação de inconstitucionalidade perante os Tribunais de Justiça. Algumas Cartas concederam tal prerrogativa inclusive aos Deputados Estaduais e Vereadores, em alguns casos isoladamente ${ }^{38}$, noutros de modo coligado. ${ }^{39-40}$

\section{TRÍPLICE PARÂMETRO NO CONTROLE JUDICIAL}

As leis e atos normativos municipais sujeitam-se, no Brasil, a um sistema de jurisdição constitucional tridimensional. A constitucionalidade das normas comunais depende de sua cumulativa compatibilidade com a Constituição Federal, com a Constituição do Estado envolvente e com a Lei Orgânica do Município respectivo.

O aferimento desses três níveis de constitucionalidade pode ser feito através de diversos instrumentos judiciais, difusos e concentrados, que serão - em diferentes graus - expostos nos próximos subtópicos.

\footnotetext{
${ }^{34} \mathrm{CRFB} / 88$, art. 125, $\S 2^{\circ}$ : "Cabe aos Estados a instituição de representação de inconstitucionalidade de leis ou atos normativos estaduais ou municipais em face da Constituição Estadual, vedada a atribuição da legitimação para agir a um único órgão".

${ }^{35}$ A Constituição do Estado de Tocantins, promulgada em 05.10.1989, não prevê um rol de legitimados a propor representação de inconstitucionalidade, perante o Tribunal de Justiça do Estado, em face de leis estaduais ou municipais que violem os seus dispositivos. Contrariando a norma inscrita no art. $125,2^{\circ}$, da Constituição da República, a Carta do Tocantins limita-se a prever, no seu art. 50, § $4^{\circ}$, IV, que constituí função institucional do Ministério Público "promover a ação de inconstitucionalidade ou de representação para fins de intervenção da União e do Estado, nos casos previstos nesta Constituição". Como mencionado acima, a Constituição Federal, ao prever a representação de inconstitucionalidade estadual, veda que a uma só autoridade seja atribuída capacidade postulatória.

${ }^{36}$ CECE, art. 127, V; CEPR, art. 111, III; CESC, art. 85, VII; CEES, art. 112, VII, CEPE, art. 63, IV; CEPB, art. 105, I, a, 6; CEMA, art. 92, III; CERO, art. 88, IV; CEAP, art. 142, IV; CEAC, art. 104, III; CEMS, art. 123, II; CEMT, art. 124, IX.

${ }^{37}$ CESP, art. 90, II; CERJ, art.162, caput; CEMG, art. 118, IV; CERS, art. 95, $\$ 1^{\circ}$, IX e X e $\S 2^{\circ}$, III e IV; CEBA, art. 134, VII; CEAM, art. 75, §1 $1^{\circ}$, IV e VI; CEPA, art. 162, V e VI; CERN, art. 71, § $2^{\circ}$, V e VII; CEPI, art. 124, IV e V; CEAL, art. 134, III e IV; CESE, art. 108, VI; CERR, art. 79, VII; CEGO, art. 60, II.

${ }^{38}$ A Constituição do Estado do Amazonas possibilita que Deputados Estaduais ou Vereadores, individualmente, proponham representações de inconstitucionalidade (CEAM, art. 75, II e V). A Constituição do Paraná prevê tal possibilidade somente aos Deputados Estaduais (CEPR, art. 111, VII).

${ }^{39}$ A Constituição do Estado de Santa Catarina concede legitimidade ativa a consórcios formados por um quarto dos parlamentares que componham cada Casa de Leis (CESC, art. 85, II e VII).

${ }^{40}$ Cabe, aqui, uma ressalva em relação à possível aplicação, em diferentes formatos, do requisito da pertinência temática, como agente limitador da capacidade postulatória para as ações diretas.
} 


\subsection{Constituição Federal}

A Constituição Federal é a Lei Maior da República, do Estado brasileiro globalmente considerado. A Constituição de 1988 não só disciplina procedimentalmente o exercício do Poder Constituinte Decorrente, como também condiciona - do ponto de vista formal e material - a validade de todas as demais normas do ordenamento por ela inaugurado, ${ }^{41}$ aí naturalmente incluídas as Constituições dos Estados e as Leis Orgânicas dos Municípios.

A aferição da compatibilidade dos atos normativos com a Constituição Federal pode ser empreendida tanto pela via difusa, quanto pela concentrada. As normas comunais só podem ter a sua constitucionalidade abstratamente sindicada, pelo Supremo Tribunal, por meio da Arguição de Descumprimento de Preceito Fundamental, uma vez que a Ação Direta de Inconstitucionalidade só se presta a impugnar leis estaduais e federais.

Sobre o ponto, há vasta produção doutrinária, de modo que remetemos o leitor ao que já se escreveu sobre o tema. ${ }^{42}$

\subsection{Constituição do Estado}

A Constituição do Estado pode, nas hipóteses previstas pela Constituição Federal, definir princípios e regras que vincularão os Municípios abrangidos pelo seu território. Como registramos ao fim do tópico 2.1, essa competência estadual não pode incidir sobre as matérias constitucionalmente reservadas às municipalidades. ${ }^{43}$ Ademais, não podem os Constituintes Estaduais, mesmo nos temas em que for lícito exercer a competência em questão, suprimir ou descaracterizar a autonomia comunal: ${ }^{44}$ princípio sensível da ordem constitucional pátria, cuja violação inclusive autoriza intervenção federal no Estado-membro transgressor (CRFB/88, art. 34, VII, $c$ ).

Feitas essas ressalvas, é preciso consignar que os atos normativos municipais - aí incluída a própria Lei Orgânica - que transgridam disposições da Constituição do Estado que os abrange, além de poderem ser incidentalmente repelidos, podem ter a sua constitucionalidade abstratamente verificada por meio da representação prevista no art. $125, \S 2^{\circ}$, da CRFB/88.

Questão interessante diz respeito à possibilidade de os Estados instituírem, por intermédio de suas respectivas Constituições, outras espécies de ações diretas que existem no plano federal, mas não foram previstas para o estadual, a exemplo da Ação Declaratória de Constitucionalidade e da Ação Direta de Inconstitucionalidade por Omissão.

\footnotetext{
41 As normas originárias da Constituição de 1988 não podem ter a sua validade questionada, fundamentam-se diretamente no Poder Constituinte Originário (v. STF, ADI 815, Rel. Min. Moreira Alves, DJe 10.05.1996). No entanto, como a forma federativa do Estado constituí cláusula pétrea (CRFB/88, art. 60, $\S 4^{\circ}$, I), a ordem constitucional brasileira não admite as emendas constitucionais que firam a autonomia dos Estados-membros ou municípios.

${ }^{4}$ Cf. BARROSO, 2012, p. 304-347. FERRARI, 2003, p. 159-232. MENDES; BRANCO, 2013 , p. $1214-1260$. OLIVEIRA, Rafael Carvalho Rezende, 2005, 74-96. TAVARES, 2000.

${ }^{43}$ Algumas vezes tal fenômeno se dá sob a categoria jurídica do "interesse local", noutras ele ocorre devido às matérias reservadas ligarem-se diretamente à capacidade de auto-organização política, administrativa ou financeira dos entes comunais.

${ }^{44}$ No tópico 2.1, destacamos a decisão exarada pelo STF no julgamento da ADI 144, relatada pelo Min. Gilmar Mendes, publicada em 03.04.2014. Oportunidade na qual o Tribunal declarou a inconstitucionalidade de norma da Constituição do Rio Grande do Norte que fixava data-limite para o pagamento de servidores públicos municipais. Nos termos do voto do Ministro Relator, tratava-se de "disposição de flagrante violação à autonomia administrativa e financeira municipal, disposta nos arts. 29; 30, I; e 34, VII, c, da Constituição Federal”. No mesmo sentido, citamos os seguintes julgados: ADI 3.548, Rel. Min. Cármen Lúcia, DJe 31.10.2007 e ADI 845, Rel. Min. Eros Grau, DJe 07.03.2008.
}

Revista de Direito Brasileira | São Paulo, SP | v. 17 | n. 7 | p. 40 - 62 | Mai./Ago. 2017 
Embora tenha havido manifestações em sentido contrário (v.g., SILVA, 2011, p. 59), prevalece que os Estados, no exercício do Poder Constituinte Decorrente, podem criar tais institutos. Mendes e Branco (2013, p. 1331) destacam o caráter ambivalente da representação de inconstitucionalidade, defendendo que a determinação constitucional para a instituição de tal mecanismos traria consigo uma autorização implícita para a criação de uma ADC estadual - que nada mais seria do que uma "ADI com sinal trocado". ${ }^{45}$ Com base em raciocínio similar, igualmente calcado na lógica da continência, tais autores também defendem a possibilidade de instituição, em âmbito estadual, de mecanismos similar à Ação Direta de Inconstitucionalidade por Omissão (MENDES; BRANCO, 2013, p. 1333-1334).

Note-se, mais uma vez com base nos levantamentos de TOMIO et al. (2015, p. 101), que as normas comunais constituem o objeto de $93,1 \%$ das ações diretas estaduais apreciadas, entre 1990 e 2013, pelos Tribunais de Justiça - dado que bem denota a atualidade da discussão quanto à constitucionalidade das normas municipais, bem como evidencia os riscos que o uso inadequado desse mecanismo pode propiciar à autonomia dos entes locais.

\subsection{Lei Orgânica do Município:}

\subsubsection{Controle Difuso}

Como a Constituição Federal não prevê mecanismo para a defesa abstrata da supremacia das Leis Orgânicas dos Municípios, o controle difuso assume acentuado relevo na jurisdição constitucional das normas comunais. ${ }^{46}$ Através dele, qualquer jurisdicionado pode pleitear a declaração incidental da invalidade de norma que com aquela seja, material ou formalmente, incompatível.

O grande entrave à eficácia sistêmica do controle de constitucionalidade difuso no Brasil sempre foi, desde o seu advento no fim do século XIX, a inexistência de mecanismos e, sobretudo, de uma cultura judiciária de valorização dos precedentes. Os esforços para garantir segurança jurídica e isonomia na jurisdição constitucional remontam à Constituição de 1934, que instituíra a reserva de plenário e previra a possibilidade de o Senado suspender a execução de norma declarada inconstitucional pelo Poder Judiciário.

Embora tais mecanismos tenham impactado positivamente na qualidade do sistema de controle de constitucionalidade pátrio, só alcançamos níveis satisfatórios de abrangência, uniformidade, segurança e efetividade quando do advento das vias abstratas e concentradas de controle de constitucionalidade, cujos provimentos revestem-se de eficácia erga omnes e efeitos vinculantes.

A tutela da supremacia da Lei Orgânica Municipal é, nessa perspectiva, mais frágil do que os sistemas protetivos das Constituições Estaduais e da Constituição Federal. Contudo, está em curso salutar processo de valorização - institucional e cultural (WOLKART, 2015, p. 409436) - dos precedentes judiciais, que promove inclusive intensa aproximação entre os sistemas jurisdicionais da Common Law e da Civil Law (MARINONI, 2009, p. 175-232). O Novo Código de Processo Civil, aprovado em março de 2015, é um nítido divisor de águas nessa matéria (MITIDIERO, 2015, p. 333-349).

Assim, espera-se que o exercício do controle de constitucionalidade incidental - e da jurisdição estatal, em geral - possa cada vez mais convergir para o modelo de stare decisis típico dos países anglo-saxões, garantindo-se provimentos, ainda que difusos, uniformes e seguros.

\footnotetext{
${ }^{45}$ No mesmo sentido, v. VELOSO, 2003, p. 345; CLÈVE, 1995, p. 269; MORAES, 2002, p. 634.

${ }^{46}$ Vimos no subtópico 2.1 que até mesmo esta possibilidade é negada por parcela minoritária da doutrina. Nesse sentido, por exemplo, v. ARAUJO; NUNES JUNIOR, 2006, p. 299
} 


\subsubsection{O Papel do Mandado de Segurança Impetrado no Curso do Processo Legislativo Municipal}

Sabe-se que a utilização do mandado de segurança contra lei em tese é proscrita. ${ }^{47}$ Entretanto, o Supremo Tribunal Federal admite, de longa data ${ }^{48}$, que o writ seja impetrado por parlamentar, contra proposição ainda em tramitação, que viole as normas constitucionais sobre processo legislativo (vício formal) ou, em se tratando de Proposta de Emenda à Constituição, haja potencial violação à cláusula pétrea (vício material).

O direito líquido e certo que autoriza, na hipótese em tela, a impetração do mandamus é o direito público subjetivo, de titularidade exclusiva dos Vereadores ${ }^{49}$, ao devido processo legislativo municipal. Por isso, tratar-se de modalidade concreta de controle de constitucionalidade que, contudo, por força dos efeitos desconstitutivos (sempre unitários) da proposição impugnada, produzirá eficácia erga omnes, obstando o próprio aperfeiçoamento do ato legislativo viciado.

No âmbito municipal, diante das restrições ao controle de constitucionalidade concentrado, o mandado de segurança pode assumir papel fulcral. ${ }^{50}$ A jurisprudência dos

\footnotetext{
${ }^{47}$ Nesse sentido, $c f$. o enunciado da Súmula 266 do STF: "Não cabe mandado de segurança contra lei em tese".

${ }^{48}$ Para ilustrar, v. STF, Tribunal Pleno, MS 20.257, Rel. p/ Acórdão Min. Moreira Alves, DJ 27.02.1981:

"Mandado de segurança contra ato da Mesa do Congresso que admitiu a deliberação de proposta de emenda constitucional que a impetração alega ser tendente a abolição da República. Cabimento do mandado de segurança em hipóteses em que a vedação constitucional se dirige ao próprio processamento da lei ou da emenda, vedando a sua apresentação (como é o caso previsto no parágrafo único do artigo 57) ou a sua deliberação (como na espécie). Nesses casos, a inconstitucionalidade diz respeito ao próprio andamento do processo legislativo, e isso porque a Constituição não quer - em face da gravidade dessas deliberações, se consumadas - que sequer se chegue a deliberação, proibindo-a taxativamente. A inconstitucionalidade, se ocorrente, já existe antes de o projeto ou de a proposta se transformar em lei ou em emenda constitucional, porque o próprio processamento já desrespeita,
} frontalmente, a Constituição".

${ }^{49}$ STF, Tribunal Pleno, MS 24667 AgR, Rel. Min. Carlos Velloso, DJ 23.04.2004: "CONSTITUCIONAL. PODER LEGISLATIVO: ATOS: CONTROLE JUDICIAL. MANDADO DE SEGURANÇA. PARLAMENTARES. I. - O Supremo Tribunal Federal admite a legitimidade do parlamentar - e somente do parlamentar - para impetrar mandado de segurança com a finalidade de coibir atos praticados no processo de aprovação de lei ou emenda constitucional incompatíveis com disposições constitucionais que disciplinam o processo legislativo".

${ }^{50}$ Embora o STF só admita a utilização do mandado de segurança contra vícios formais (além da hipótese excepcional do controle de constitucionalidade de emenda à Constituição violadora de cláusula pétrea), parecer-nosia razoável que, na seara municipal, tal possibilidade fosse elastecida para abarcar, além das infrações às normas de processo legislativo inscritas na Lei Orgânica do Município, as ofensas frontais, de quaisquer proposições legislativas, a disposições literais, de cunho material, que constem da Constituição Municipal. Essa seria uma forma eficaz de driblar a ausência de via abstrata de controle de constitucionalidade do Direito Municipal em face da Lei Orgânica. Contudo, as críticas da doutrina e do próprio Supremo à inauguração pretoriana de um sistema judicial de controle prévio da constitucionalidade das leis parecem procedentes, de modo que nos furtamos de defender a tese cogitada. Nesse sentido, v. STF, Tribunal Pleno, MS 32033, Rel. Min. Gilmar Mendes, Rel. p/ Acórdão Min. Teori Zavascki, DJe 18.02.2014: "CONSTITUCIONAL. MANDADO DE SEGURANÇA. CONTROLE PREVENTIVO DE CONSTITUCIONALIDADE MATERIAL DE PROJETO DE LEI. INVIABILIDADE. 1. Não se admite, no sistema brasileiro, o controle jurisdicional de constitucionalidade material de projetos de lei (controle preventivo de normas em curso de formação). O que a jurisprudência do STF tem admitido, como exceção, é "a legitimidade do parlamentar - e somente do parlamentar - para impetrar mandado de segurança com a finalidade de coibir atos praticados no processo de aprovação de lei ou emenda constitucional incompatíveis com disposições constitucionais que disciplinam o processo legislativo" (MS 24.667, Pleno, Min. Carlos Velloso, DJ de 23.04.04). Nessas excepcionais situações, em que o vício de inconstitucionalidade está diretamente relacionado a aspectos formais e procedimentais da atuação legislativa, a impetração de segurança é admissível, segundo a jurisprudência do STF, porque visa a corrigir vício já efetivamente concretizado no próprio curso do processo de formação da norma, antes mesmo e independentemente de sua final aprovação ou não. 2. Sendo inadmissível o controle preventivo da constitucionalidade material das normas em curso de formação, não cabe atribuir a parlamentar, a quem a Constituição nega habilitação para provocar o controle abstrato repressivo, a prerrogativa, sob todos os aspectos mais abrangente e mais eficiente, de provocar esse mesmo controle antecipadamente, por via de mandado de segurança. 3 .

Revista de Direito Brasileira | São Paulo, SP | v. 17 | n. 7 | p. 40 - 62 | Mai./Ago. 2017 
Tribunais de Justiça vem, na linha preconizada pelo Supremo, respaldando a utilização do mandado de segurança para anular projetos de lei infringentes de normas de processo legislativo previstas pela Lei Orgânica Municipal. Os seguintes julgados ilustram essa tendência:

MANDADO DE SEGURANÇA - CÂMARA DE VEREADORES APROVAÇÃO DE PROJETO DE LEI - QUORUM INSUFICIENTE DIREITO LÍQUIDO E CERTO VIOLADO. 1. É o mandado de segurança instrumento hábil para anular deliberação ilegal de Câmara Municipal, aprobatória de projeto de lei com infração de dispositivo de regimento interno da Câmara e da Lei Orgânica dos Municipios, uma vez que o vício de tramitação do processo legislativo é suscetível de ferir direito líquido e certo, não obstante a não aplicação em concreto da regra editada. (TJ/SC, Primeira Câmara de Direito Civil, Apelação Cível em Mandado de Segurança n. 99.008617-8, Relator: Newton Trisotto, Data de Julgamento: 24.02.2000).

****

Apelação Cível - Mandado de segurança. Vício na tramitação de processo legislativo. Vereador. Legitimidade e cabimento. Apelo provido. Unânime. Tem o vereador legitimidade para tanto e é cabível o mandado de segurança objetivando atacar vício na tramitação de processo legislativo. - Apelo provido. Decisão unânime. (TJ/SE, $1^{\text {a }}$ Câmara Cível, AC: 1999204936 SE, Relator: DES. FERNANDO RIBEIRO FRANCO, Data de Julgamento: 14.08.2001).

$$
* * *
$$

Mandado de Segurança. Impetração interposta por vereador questionando a aprovação de projeto de lei. Extinção do processo afastada. Impetração de caráter preventivo que não se volta contra lei em tese, mas sim, contra o alegado desrespeito às normas regimentais do processo legislativo municipal. Precedentes jurisprudenciais do STF e STJ. Segurança concedida. (TJ/SP, $13^{\mathrm{a}}$ Câmara de Direito Público, Apelação com Revisão n ${ }^{\circ}$ 2930615/0, Des. Rel. Oliveira Passos, DJe 14.08.2007).

PROCESSO LEGISLATIVO MUNICIPAL. MANDADO DE SEGURANÇA. PRELIMINARES DE NULIDADE DO FEITO E AUSÊNCIA DE INTERESSE DE AGIR. AFASTAMENTO. CONVOCAÇÃO PARA SESSÃO EXTRAORDINÁRIA. INOBSERVÂNCIA FORMALIDADES PREVISTAS PELA LEI ORGÂNICA MUNICIPAL. NULIDADE. VÍCIO FORMAL. SEGURANÇA CONCEDIDA. (...) 2. Caso em que se identifica mácula no processo legislativo municipal. Vício formal na convocação dos vereadores para sessão extraordinária em véspera do recesso de final de ano, já que inobservada a condição de maioria absoluta prevista pela Lei Orgânica Municipal. Ausência de convocação expressa e pessoal para a sessão que corrobora o reconhecimento da nulidade. (TJ/RS, Segunda Câmara Cível, Apelação nº 70069546729, Des. Rel. Ricardo Torres Hermann, DJe 04.08.2016).

A prematura intervenção do Judiciário em domínio jurídico e político de formação dos atos normativos em curso no Parlamento, além de universalizar um sistema de controle preventivo não admitido pela Constituição, subtrairia dos outros Poderes da República, sem justificação plausível, a prerrogativa constitucional que detém de debater e aperfeiçoar os projetos, inclusive para sanar seus eventuais vícios de inconstitucionalidade. Quanto mais evidente e grotesca possa ser a inconstitucionalidade material de projetos de leis, menos ainda se deverá duvidar do exercício responsável do papel do Legislativo, de negar-lhe aprovação, e do Executivo, de apor-lhe veto, se for o caso. Partir da suposição contrária significaria menosprezar a seriedade e o senso de responsabilidade desses dois Poderes do Estado. E se, eventualmente, um projeto assim se transformar em lei, sempre haverá a possibilidade de provocar o controle repressivo pelo Judiciário, para negar-lhe validade, retirando-a do ordenamento jurídico. 4. Mandado de segurança indeferido". 
Em recapitulação do exposto, pode-se dizer que tem o Vereador, e somente ele, legitimidade para, por meio de mandado de segurança impetrado no curso do processo legislativo $^{51}$, obstar a aprovação de projetos de lei inquinados de vícios formais de inconstitucionalidade ou de emendas à Lei Orgânica do Município que violem cláusulas pétreas. ${ }^{52}$ Como afirmamos, essa é uma importante ferramenta para a jurisdição constitucional das normas comunais, não só pela já apontada insuficiência dos mecanismos abstratos, mas também porque grande parte dos problemas de inconstitucionalidade que contaminam a produção legislativa municipal são formais: vício de iniciativa, usurpação da competência legislativa de outros entes, ofensa à separação dos Poderes, geração de despesas sem a indicação da fonte de custeio, desrespeito aos quóruns constitucionalmente exigidos etc.

\subsubsection{Podem as Constituições Estaduais Criar Mecanismo para o Controle Concentrado das Normas Municipais, pelo Tribunal de Justiça, tendo como Parâmetro a Lei Orgânica?}

O mecanismo ora tratado não foi previsto na Constituição Federal de 1988, embora o tenha sido em algumas Constituições Estaduais - a exemplo da Constituição do Estado de Pernambuco, que previu competir ao Tribunal de Justiça do Estado julgar a representação de inconstitucionalidade "de lei ou ato normativo municipal em face da Lei Orgânica respectiva". 53

O propósito deste subtópico é, justamente, examinar a viabilidade jurídica desse mecanismo. Pode a Constituição de Estado-membro instituir ferramenta de controle de constitucionalidade não prevista pela Constituição Federal?

A Procuradoria-Geral da República acredita que a resposta a tal indagação deve ser negativa, tanto que propôs, no dia 20.06.2016, Ação Direta de Inconstitucionalidade (ADI $n^{\circ}$ 5548) contra o dispositivo da Constituição pernambucana que fora acima transcrito. Aduz o Ministério Público Federal, às fls. 4/5 da exordial aludida, que a "Lei orgânica municipal não possui status de norma constitucional, razão pela qual é inadmissível sua utilização como parâmetro de controle de constitucionalidade de normas municipais". 54

Como observamos no tópico 2.1, a Lei Orgânica é justamente o principal e mais emblemático produto da capacidade auto-organização do Município - enquanto componente da Federação brasileira. Trata-se de diploma que, além de possuir conteúdo tipicamente constitucional (consagra direitos, estabelece o procedimento legislativo e define os poderes que competem a cada órgão estatal), goza de induvidosa superioridade formal em relação às demais normas da respectiva comuna (ex vi do art. 29, caput, da CRFB/88).

\footnotetext{
${ }^{51}$ TJ/SP, $3^{\text {a }}$ Câmara de Direito Público, Apelação no 0001118- 27.2012.8.26.0281, Des. Rel. Amorim Cantuária, DJ $e$ 31.10.2012: "APELAÇÃO. MANDADO DE SEGURANÇA. VEREADOR. Mandado de segurança impetrado por parlamentar, findo o processo legislativo. Impossibilidade. Pretensão à suspensão da vigência e declaração de nulidade de leis municipais fundada na afirmação de inobservância de quórum previsto no artigo 34 da Lei Orgânica Municipal. Inadequação da via eleita. Sentença que julgou improcedente o pedido nos termos do artigo 267, inciso VI, do Código de Processo Civil. Manutenção. RECURSO DESPROVIDO".

${ }^{52}$ Tais cláusulas pétreas estão inscritas na Constituição Federal e, em alguns casos, na própria Lei Orgânica do Município respectivo. Para ilustrar, v. Lei Orgânica do Município do Rio de Janeiro, art. 68, § 4: "Não será objeto de deliberação a proposta de emenda tendente a: I - arrebatar ao Município qualquer porção de seu território; II abolir a autonomia do Município; III - alterar ou substituir os símbolos ou a denominação do Município".

${ }^{53}$ CEPE: “Art. 61. Compete ao Tribunal de Justiça: I - processar e julgar originariamente: (...) l) a ação direta de inconstitucionalidade de lei ou ato normativo estadual ou municipal, em face desta Constituição, ou de lei ou ato normativo municipal em face da Lei Orgânica respectiva".

${ }^{54}$ Em sede doutrinária, Rogério Gesta Leal manifestou-se no mesmo sentido: "Por fim, cabe a ressalva de que não se poderá ter, ao menos na atual sistemática jurídica vigente, ação direta de inconstitucionalidade por lesão à lei orgânica do município, em nome de eventual simetria desta para com a Constituição Estadual e Federal, eis que sua natureza é de lei e não constitucional, caracterizando eventual vício mera ilegalidade e não inconstitucionalidade" (LEAL, 2013, p. 1.513).
} 
Na página 06 da petição inicial da ADI no 5548, o Procurador-Geral da República defende que o "Supremo Tribunal Federal, no julgamento do recurso extraordinário 175.087/SP, reputou incabível controle concentrado de constitucionalidade de lei municipal em face de lei orgânica municipal". O caso apreciado, nesta oportunidade, tratava-se, na origem, de representação de inconstitucionalidade intentada pelo Prefeito de São Bernardo do Campo, com base na Lei Orgânica daquela municipalidade, contra norma aprovada pela respectiva Câmara de Vereadores. Contudo, diversamente do que ocorre em Pernambuco, a Constituição bandeirante não admite o controle abstrato de normas comunais com base na Lei Orgânica do respectivo Município. Assim, não havendo previsão constitucional - nem na Carta Federal, nem na Estadual - de tal mecanismo, não restou outra alternativa à Suprema Corte a não ser reconhecer que o referido alcaide carecia de ação.

A discussão ora proposta é outra. Trata-se, como já antecipado, de definir se é dado ao Poder Constituinte Decorrente criar mecanismo abstrato de tutela da supremacia da Lei Orgânica do Município, mesmo à mingua de previsão pela Constituição Federal de instituto nesse sentido. Para parte dos constitucionalistas, essa complexa questão poderia ser apressadamente encerrada com simples menção ao pretoriano princípio da simetria ou qualquer outro artifício refreador da autonomia política dos entes federados regionais e locais. ${ }^{55}$

De nossa parte, acreditamos que o deslinde da questão é mais complexo. O caput, do art. 125, da Constituição Federal, prevê que os "Estados organizarão sua Justiça, observados os princípios estabelecidos nesta Constituição”. O parágrafo primeiro do citado artigo estabelece que as competências de tais Tribunais serão definidas na Constituição de cada Estado-membro. No parágrafo subsequente, a Constituição Federal atribuí aos Estados o dever de instituir "representação de inconstitucionalidade de leis ou atos normativos estaduais ou municipais em face da Constituição Estadual, vedada a atribuição da legitimação para agir a um único órgão".

Será que esta norma atributiva de uma relevante competência traz, implícita no seu espírito, uma restrição à faculdade de auto-organização da Justiça Estadual - assegurada, em termos latos, nos dispositivos antecedentes? Ao que parece, o telos do art. $125, \S 2^{\circ}$, da Constituição Federal não parece ser impedir a criação de mecanismos de jurisdição constitucional abstrata com base na Lei Orgânica Municipal, mas, ao revés, garantir a instituição de ferramentas do gênero para tutelar a supremacia da Constituição do Estado.

Ademais, cumpre notar que o dispositivo em apreço presta deferência à liberdade de conformação do Constituinte Decorrente, ao assegurar que a configuração básica do instituto fique a cargo de cada Constituição Estadual - veda-se apenas a atribuição de capacidade postulatória a um único órgão.

Como oportunamente lembra Slaibi Filho (1995, p. 95), são reservadas aos Estados as competências que não lhes tenham sido vedadas pela Constituição Federal. ${ }^{56}$ Não se pode, por via hermenêutica, inverter a lógica constitucional acima enunciada, para fazer com que quando a Constituição Federal expressamente atribua determinada competência aos Estados, esteja ela também, pari passu, negando-lhes outras atribuições correlatas àquela - sobre as quais o Constituinte silenciou.

\footnotetext{
55 De fato, reconheça-se, a questão não é simples. Trata-se da instituição - pelo Constituinte Estadual - de mecanismo jurisdicional de controle de constitucionalidade especificamente incidente sobre a legislação municipal, a ser exercido por órgão estadual (pelo Tribunal de Justiça), independentemente de previsão pela Carta da República. Contudo, o mecanismo criado pela Constituição do Estado de Pernambuco não parece ser ofensivo à autonomia do Município, pelo contrário. Ressalvadas deliberadas distorções no seu manejo, a ferramenta pode contribuir em muito com a defesa da higidez da ordem jurídica municipal e, especialmente, com a tutela da supremacia da Lei Orgânica do Município em relação às demais normas comunais. Nesse sentido, acreditamos estar diante de mecanismo que não só pode aperfeiçoar o sistema de jurisdição constitucional pátrio, bem como promove o espírito federalista.

${ }^{56}$ Nesse sentido, dispõe o art. $25, \S 1^{\circ}$, da CRFB/88: "São reservadas aos Estados as competências que não lhes sejam vedadas por esta Constituição".
} 


\section{PROPOSIÇÕES CONCLUSIVAS}

A vida e a cidadania são exercidas primordialmente nos Municípios: entes indisputavelmente incluídos no pacto federativo brasileiro pela Constituição de 1988. Essa categoria federativa, composta por 5.570 municipalidades, é profundamente heterogênea. Enquanto algumas comunas são política e economicamente mais relevantes do que diversos Estados-membros, outras são precariamente estruturadas e contam com poucas centenas de habitantes.

De modo geral, as Câmaras de Vereadores brasileiras - mesmo em cidades importantes - são ocupadas por mandatários e funcionários públicos de apoio, em grande medida comissionados, insuficientes e pouco capacitados. Essa é uma das principais razões que explicam um fenômeno perverso: a inconstitucionalidade sistêmica da legislação municipal brasileira.

Em 2013, por exemplo, só o Tribunal de Justiça de São Paulo julgou procedentes 354 representações de inconstitucionalidade propostas contra leis municipais. Tal número correspondente a $65 \%$ dos diplomas comunais que tiveram a sua constitucionalidade questionada, por tal via, no âmbito daquele Tribunal. ${ }^{57}$

Nesse contexto, o presente estudo procurou fazer abrangente radiografia do sistema de controle de constitucionalidade dos atos normativas municipais, abarcando todos os mecanismos políticos e jurisdicionais que o integram.

Como premissas gerais, defendemos a natureza constitucional das Leis Orgânicas Municipais e o status de efetiva entidade federativa dos Municípios. Em seguida, analisamos os instrumentos de controle de constitucionalidade a cargo das Câmaras Municipais, destacando especialmente o papel das Comissões de Constituição e Justiça, os mecanismos sustatórios e a possibilidade de controle pela via legislativa propriamente dita.

$\mathrm{Na}$ sequência, debruçamo-nos sobre os mecanismos incumbidos aos Prefeitos, dedicando especial atenção ao veto por inconstitucionalidade, à possibilidade de recusa ao cumprimento de lei reputada inconstitucional, à utilização do poder regulamentar para engendrar interpretação conforme a Constituição e, por fim, à capacidade de propor ações impugnativas de diplomas inconstitucionais.

Vistas as ferramentas políticas de controle de constitucionalidade, adentramos na seara judicial. De início, defendemos a existência de três parâmetros autônomos para o controle de constitucionalidade da produção normativa comunal. Tecemos, então, sucinto comentário sobre as - já largamente estudadas pela doutrina - ferramentas de garantia da supremacia da Constituição Federal sobre as leis municipais. Em seguida, abordamos os mecanismos de defesa da superioridade da Constituição do Estado envolvente, oportunidade em que também traçamos limites a essa supremacia.

Com maior detença, finalmente, discutimos as ferramentas de impugnação de normas comunais incompatíveis com a Lei Orgânica Municipal. Após breves comentários a respeito do exercício da jurisdição constitucional difusa, discutimos o papel do Mandado de Segurança impetrado, por Vereador no curso do processo legislativo municipal, para questionar vícios formais da proposição em trâmite ou obstar a promulgação de proposta de emenda à Lei Orgânica que atente contra cláusula pétrea.

Por derradeiro, defendemos a possibilidade de os Estados-membros instituírem, por meio de suas Constituições, representação de inconstitucionalidade que tenha como parâmetro a Lei Orgânica Municipal e objeto os atos normativos produzidos pela respectiva comuna.

\footnotetext{
${ }^{57}$ Dados obtidos no Anuário da Justiça São Paulo 2014. São Paulo: Conjur Editorial, 2014. Notícia que divulga os dados citados pode ser acessada por meio do seguinte endereço eletrônico: 〈http://www.conjur.com.br/2014-mar-17/tj-sp-apontou-inconstitucionalidade-65-leis-questionadas-2013〉. Data de acesso: 06.12.2016.
}

Revista de Direito Brasileira | São Paulo, SP | v. 17 | n. 7 | p. 40 - 62 | Mai./Ago. 2017 


\section{REFERÊNCIAS BIBLIOGRÁFICAS}

ACCIOLY, João Pedro. O Sistema de Jurisdição Constitucional Francês: Do Primado da Lei à Questão Prioritária de Constitucionalidade. Revista de Direito Constitucional e Internacional, v. 96, ano 24, p. 231-246, São Paulo: Ed. RT, 2016.

ALVES, José Carlos Moreira. O problema do controle da constitucionalidade dos atos normativos federais, estaduais e municipais. Revista Jurídica da Procuradoria-Geral do Distrito Federal, Brasília, v. 36, p. 9-25.

ARAUJO, Alberto David; NUNES JUNIOR, Vidal Serrano. Curso de Direito Constitucional. 10 ed. São Paulo: Saraiva, 2006.

BARROSO, Luís Roberto. A razão sem voto: o Supremo Tribunal Federal e o governo da maioria. Revista Brasileira de Políticas Públicas, Brasília, v. 5, Número Especial, 2015 p. 23-50.

2012.

O Controle de Constitucionalidade no Direito Brasileiro. $6^{\text {a }}$ ed. São Paulo: Saraiva,

Poder Executivo - Lei Inconstitucional - Descumprimento (Parecer). Revista de Direito Administrativo, vol. 181/182, p. 387-397, 1990.

BINENBOJM, Gustavo. A nova jurisdição constitucional Legitimidade democrática $e$ instrumentos de realização. $3^{\mathrm{a}}$ ed. Rio de Janeiro: Renovar, 2010.

BRANDÃO, Rodrigo. Supremacia Judicial versus Diálogos Constitucionais. Rio de Janeiro: Editora Lumen Juris, 2012.

BUENO, Pimenta José Antonio (Marquês de São Vicente). Direito Publico Brazileiro e Analyse da Constituição do Imperio. Rio de Janeiro: Typographia Imp. e Const. de J. Villeneuve e C., 1857.

CANOTILHO, J. J. Gomes; MENDES, Gilmar F.; SARLET, Ingo W.; STRECK, Lenio L. Comentários à Constituição do Brasil. São Paulo: Saraiva/Almedina, 2013

CLÈVE, Clèmerson Merlin. A fiscalização abstrata da constitucionalidade no direito brasileiro. $2^{a}$ ed. São Paulo: Revista dos Tribunais, 2000.

CYRINIO, André Rodrigues. Revolução na Inglaterra? Direitos humanos, corte constitucional e declaração de incompatibilidade das leis: novel espécie de judicial review?. RDE - Revista de Direito do Estado, n. 5, p. 267-288, jan./mar. 2007.

DALLARI, Dalmo de Abreu. Lei municipal inconstitucional. In: PROCURADORIA-GERAL DO ESTADO DE SÃO PAULO. Ação direta de controle da constitucionalidade de leis municipais, em tese. São Paulo: Centro de Estudos da Procuradoria-Geral do Estado, 1979, p. 115-126. 
FERRARI, Maria Regina Macedo Nery. Controle de constitucionalidade de lei municipal. $3^{\mathrm{a}}$ ed. São Paulo: Revista dos Tribunais, 2003.

Direito Municipal. 2a ed. São Paulo: Revista dos Tribunais, 2005.

FERRARI, Sérgio. Constituição Estadual e Federação. Rio de Janeiro: Lumen Juris, 2003.

FERRAZ, Ana Cândida da Cunha. Poder constituinte do estado-membro. São Paulo: Revista dos Tribunais, 1979.

- Conflito entre poderes. O poder congressual de sustar atos normativos do Poder Executivo. São Paulo: Editora Revista dos Tribunais, 1994.

FRIESENHANHN, Ernst. La giurisdizione constituzionale nella Repubblica federale tedesca. Trad. Angelo Antonio Cervati. Milano: Giuffrè, 1973.

GIUSTINA, Vasco Della. Leis municipais e seu controle pelo tribunal de justiça. Porto Alegre: Livraria do Advogado, 2001.

GOMES, Juliana Cesario Alvim. Por um constitucionalismo difuso: cidadãos, movimentos sociais e o significado da Constituição. Salvador: Editora JusPodivm, 2016.

HORTA, Raul Machado. Direito constitucional. 4.ed. Belo Horizonte: Del Rey, 2003. . Estudos de Direito Constitucional. Belo Horizonte: Del Rey, 1995.

IVO, Gabriel. Constituição estadual: competência para elaboração da Constituição do Estadomembro. São Paulo: Max Limonad, 1997.

LEONCY, Léo Ferreira. Controle de Constitucionalidade Estadual: as normas de observância obrigatória e a defesa abstrata da Constituição do Estado-membro. São Paulo: Saraiva, 2007.

MARINONI, Luiz Guilherme. Aproximação Crítica entre as Jurisdições de Civil Law e de Common Law e a Necessidade de Respeito aos Precedentes no Brasil. Revista de Processo, v. 172, p. 175-232, 2009.

MELLO, José Luiz de Anhaia. Da separação de poderes à guarda da Constituição: as cortes constitucionais. São Paulo: Revista dos Tribunais, 1968.

MENDES, Gilmar Ferreira. O Poder Executivo e o Poder Legislativo no controle de constitucionalidade. Revista de Informação Legislativa, v. 34, p. 11-39, 1997.

MENDES, Gilmar Ferreira; BRANCO, Paulo Gustavo Gonet. Curso de Direito Constitucional. $8^{\mathrm{a}}$ ed. São Paulo: Saraiva, 2013. 
MITIDIERO, Daniel. Precedentes, Jurisprudência e Súmulas no Novo Código de Processo Civil Brasileiro. Revista de Processo, v. 245, p. 333-349, 2015.

MORAES, Alexandre. Direito constitucional. 11. ed. São Paulo: Atlas, 2002.

NEVES, Marcelo. Teoria da inconstitucionalidade das leis. São Paulo: Saraiva, 1988.

NOVELINO, Marcelo. Direito Constitucional. $3^{\text {a }}$ ed. São Paulo: Editora Método, 2009.

OLIVEIRA, Rafael Carvalho Rezende. O controle abstrato de constitucionalidade da lei municipal e a autonomia federativa. Direito, Estado e Sociedade, v. 26, p. 74-96, 2005.

ROCHA, Fernando Luiz Ximenes. Controle de constitucionalidade das leis municipais. São Paulo: Ed. Atlas, 2003.

SARMENTO, Daniel; SOUZA NETO, Cláudio Pereira de. Direito Constitucional: teoria, história e métodos de trabalho. Belo Horizonte: Editora Fórum, 2013.

SILVA, José Afonso da. Curso de Direito Constitucional Positivo. 34 ed. São Paulo: Malheiros, 2011.

SLAIBI FILHO, Nagib. Ação declaratória de constitucionalidade. $2^{\mathrm{a}}$ ed. Rio de Janeiro: Forense, 1995.

SOARES, Humberto Ribeiro. Pode o Executivo deixar de cumprir uma Lei que ele próprio considere inconstitucional?. Revista de Direito da Procuradoria Geral (PGE/RJ). Vol. 50, p. 519-551, 1997.

STRECK, Lenio Luiz. Jurisdição Constitucional e Hermenêutica: Uma Nova Crítica do Direito. Porto Alegre: Livraria do Advogado, 2002.

TAVARES, André Ramos. Da arguição de descumprimento de preceito constitucional fundamental. Tese (Doutorado em Direito Constitucional) Programa de Estudos Pós-Graduados em Direito, Pontifícia Universidade Católica de São Paulo, São Paulo, 2000.

TOCQUEVILLE, Alexis de. A democracia nas Américas. Trad. J. A. G. Albuquerque. São Paulo: Editora Abril, 1973.

TOMIO, F. R. L.; ROBL FILHO, I. N.; KANAYAMA, R. L. Constitucionalismo estadual e controle abstrato e concentrado de constitucionalidade nos Tribunais de Justiça: efeitos das Ações Diretas de Inconstitucionalidade (ADI) estaduais na federação brasileira. Revista de Direito Brasileira, vol. 12, p. 87-110, 2015. Disponível em: <http://www.rdb.org.br/ojs/index.php/rdb/article/view/350/222>. Acesso em: 06/03/2017.

VELOSO, Zeno. Controle Jurisdicional de Constitucionalidade. Belo Horizonte: Del Rey, 2000. 
WOLKART, Erik Navaro. Precedentes no Brasil e cultura: um caminho tortuoso, mas, ainda assim, um caminho. Revista de Processo, v. 243, p. 409-436, 2015.

ZIMMERMANN, Augusto. Teoria Geral do Federalismo Democrático. $2^{a}$ ed. Rio de Janeiro: Editora Lumen Juris, 2005. 